\title{
STRATEGIC PLANNING FOR COMMUNITY SUSTAINABILITY IN MODEL FORESTS: CASE STUDY OF THE YORO MODEL FOREST, HONDURAS
}

\author{
Vignote S. ${ }^{1}$, Martínez-Rojas I. ${ }^{2}$, Pérez-Fernández S. ${ }^{2}$, Rejas M. ${ }^{2}$, Sánchez J. ${ }^{3}$, Martínez K. ${ }^{4}$, \\ Vignote-Hernández S. ,
}

\begin{abstract}
This study proposes the strategic planning process for development in model forests, based on the case study of the Yoro Model Forest in Honduras. In this forest the timber industry -and specifically the carpentry and furniture subsector- has the greatest competitive potential for supplying products for export and generating wealth in the area, given the region's scant purchasing capacity. Strategic analysis, strategic choice and strategic implementation are applied to this subsector, and the results show that the subsector could be developed by creating a cooperative enterprise capable of supplying furniture parts to an international company whose marketing strategy includes the sale of natural, environmentally-sustainable furniture, and which has a policy of social engagement.
\end{abstract}

Keywords: Model forests, small-scale carpentry industries, small-scale furniture industries, strategic planning.

\section{INTRODUCTION}

The model forest first emerged in Canada in the 1990s, with the aim of integrating the principles of sustainable development into forestry. At the initiative of the Canadian Prime Minister, the International Model Forest Network (IMFN) was created in 1992 to mark the United Nations Conference on Environment and Development (UNCED) in Rio de Janeiro, and by 2011 it comprised 58 forests belonging to 24 countries, covering over 108 million hectares and home to several million people (IMFN 2011).

When a model forest is created, individuals and groups supporting a wide variety of forest assets agree to work together to design and trial ways of managing natural resources and forest landscapes, using approaches that are both acceptable at the local level and significant at the national level. The governance of a model forest is based on consensus, as it allows all the participants to express their opinion and play a part in the activities carried out there. The governance structure is highly flexible and designed to reflect the cultural, social, political and economic situation of the area where the model forest operates. Stakeholders commonly include users, landowners and administrators, forestry industries, community groups, NGOs, government bodies, academic and research institutions and indigenous groups, among others (RIABM 2015).

\footnotetext{
${ }^{1}$ Universidad Politécnica de Madrid (UPM), Ciudad Universitaria, Madrid, Spain.

${ }^{2}$ Universidad Politécnica de Madrid (UPM), Madrid. España.

${ }^{3}$ Escuela Nacional de Ciencias Forestales (U-ESNACIFOR), Siguatepeque, Honduras.

${ }^{4}$ Bosque Modelo de Yoro, Yoro, Honduras.

${ }^{5}$ Escuela de Ingenieros de Montes, Universidad Politécnica de Madrid (UPM), Madrid. España.

"Corresponding author: santiago.vignote@upm.es
}

Received: 17.07.2015 Accepted: 18.02.2016 
The participants in the 2008 IMFN World Forum identified strategic initiatives to allow their members to develop and implement programming priorities for issues that go beyond particular model forests. These initiatives are: climate change and its possible association with the programme for Reducing Emissions from Deforestation and Forest Degradation (REDD); ecological goods and services, and the possibility of accessing payment for ecological goods and services; and community sustainability and economic development, an initiative designed to improve the quality of life of the members of the communities participating in the model forest according to the particular economic situation of each one.

The 28 projects on community sustainability and economic development (RIABM, 2015) have generally set out to reinforce local capacity in agriculture, livestock farming, non-timber forestry products, crafts, tourism and others. There are no structured values for strategic planning; the only reference is to a strategic development project in the Campo Ma'an Model Forest in Cameroon, but this discusses ways for different stakeholders to proceed to define the problems, solutions and actions for the benefit of all the stakeholders, rather than to a structured strategic planning (Jum et al. 2007).

Another reference to strategic planning is the work on the systematisation of forestry strategy in the Lachuá Ecoregion, Cobán, Alta Verapaz, Guatemala (Palacios and Vaides 2011). This initiative aimed to create forestry plantations in deteriorating areas of the model forest, but did not extend to supporting the development of the communities.

Strategic planning is a systematic process for enabling a company or organisation to define its longterm vision and the strategies required to achieve it, based on the analysis of its strengths, weaknesses, opportunities and threats (Serna-Gómez 1994). It originated in the 1960s, and is currently widely used in a far greater number of fields than originally envisaged, although its primary sphere of application is in strategic planning in organisations, institutions and cities (Gil-Zafra 2001).

The main contributions of strategic planning when compared to the traditional approach are essentially: A) the incorporation of the actors or socio-economic agents with a stake in the territory; B) the dimensioning of the territory as something more than merely a physical space; and C) the fact that it considers the objectives and strategies in a dynamic way in order to adapt to a changing environment (Gil-Zafra 2001).

Strategic planning has been used in the forestry industry to provide a useful overview and enable major problem areas to be identified (García-Jiménez et al. 2013, Rauch 2007).

David Ricardo's theory of comparative advantage suggests that it is logical for a country to specialise in producing the commodities it can produce most efficiently, and to acquire those that it cannot. Unlimited free trade leads to an increase in world production, and by embracing free trade a country stimulates its economic growth and generates an increase in revenues (Hill 2007).

The Heckscher-Ohlin model maintains that the pattern of international trade is determined by differences in factor endowments. This theory also holds that countries should export goods that make intensive use of locally abundant factors, and import goods that make intensive use of locally scarce factors (Hill 2007).

Two key competitive advantages over other industries located in different areas are the large amounts of local raw materials available and the low labour costs for local timber industries (furniture and carpentry) inside most of the Model Forests. 
Mejía et al. (1996) conducted a SWOT analysis of a sample of 185 firms located in Siguatepeque and San Pedro Sula, out of the 1000 companies existing in Honduras, and found that industries with sufficient productive capacity can be enhanced by providing more training for the workforce, and exploiting the subproducts of timber processing. Timber products from Honduras are recognised worldwide; however, the output from the industries in these two regions is mainly limited to the local market. The proposal was to create strategic alliances and clusters to improve the production potential of the timber processing firms, and devise market strategies to position the products in the international market. It was further proposed that the development of this sector should be driven by creating and reinforcing business networks, operating as work clusters and alliances with external cooperation organisations with which they could purchase raw materials in bulk and negotiate lower prices for their supplies.

The objective of this investigation were to create a strategic plan for the carpentry and furniture sector located in the Yoro Model Forest (Honduras) and serve as the basis for improvements in the competitiveness of these companies and in the wellbeing of the people in the local communities.

\section{METHODOLOGY}

Strategic planning is the process of determining an organisation's main objectives and the criteria for managing resources in order to achieve these objectives. The planning process comprises the following stages: strategic analysis, strategic choice and strategic implementation (Johnson and Scholes 1997).

\section{Strategic analysis (SWOT matrix)}

A strategic decision must be based on a broad approach to the current conditions of the study area. SWOT matrix is a simple but complete tool to analyze a whole set of critical strategic data and support the MOC (management of change) inside the Organizations.

Although there are several versions of the SWOT matrix in the bibliography -TOWS analysis, balanced scorecard SWOT analysis- we decided to use the original matrix for the analysis, also known as the Harvard model, with the following considerations (Gil-Zafra 2001):

SWOT analysis aims to establish the current actual situation inside an organisation (Strengths and Weaknesses) and the external market forces (Threats and Opportunities) that could impact its competitiveness (Talancón 2007).

- For external references from international sources we consulted the United Nations Development Programme (UNDP) (Malik 2014), Fundación WageIndicator 2015, Worldbank 2015 and the Instituto Universitario en Democracia, Paz y Seguridad (IUDPS 2013) for general information about the country. Forest data were obtained from the United Nations Food and Agriculture Organization (FAO) (Morales et al. 2002, Richards et al. 2003).

- A stakeholder survey was conducted to obtain the local data, and the Yoro Model Forest Association provided some information and data (RIABM 2015).

The stakeholder survey analysed the whole local population of carpenters and furniture makers by collecting information from the National Forestry Sciences School (ESNACIFOR), the National Institute for the Conservation and Development of Forestry, Protected Areas and Wildlife (ICF) and the Association of Forestry Professionals in Honduras, although the initial list was extended based on the information obtained from the carpenters themselves.

The surveys were designed in the form of direct personal interviews (occasionally by phone) covering a range of topics containing both quantitative and qualitative elements, with the help of a written questionnaire prepared according to Vallejo (2011). 
The questionnaire is unstructured, and the questions therefore do not follow a strict order or sequence, with a few exceptions. This enables the vocabulary to be adapted to the respondent's education level, and offers greater leeway and flexibility in formulating specific questions.

The questions concerning characteristics intrinsic to the firm -such as machinery, techniques and technology- were designed to be semi-open, and always allowed the option of answering with new responses which would enrich the knowledge of the local industry.

For questions about the extrinsic factors with an influence in the environment, it is first necessary to discover whether the owners are aware of the deficiencies and opportunities in their firm and operating market by means of open questions that enable the owner to participate and engage in the vision of the project for improvement, despite the anticipated difficulty in tabulating their results.

The questionnaire was designed based on the following considerations:

- The use of vocabulary and terms were appropriate to the local language of the trade.

- The questions were formulated in a clear and unequivocal way.

- The survey began with the simplest questions and gradually increased in complexity.

- Particular care was taken with questions that could be delicate or embarrassing for the respondent, framing them in such a way that the information could be elicited without causing refusal or untruthful responses.

- There were no questions containing value judgements or statements.

- The questions were formulated so the respondent would not need to make a significant effort of memory or calculations, in order to avoid errors in the answers.

Some combined filter and control questions were also formulated.

With regard to the content of the questions, the questionnaire begins with several identifying questions to obtain the respondents' personal details, and continues with questions on opinion, information, motives and technical issues.

The questionnaire is structured in short themed modules in the following order:

- Firm's organisation and facilities

- Characteristics of the raw material, quantity, species and dimensions

- Drying techniques and knowledge of green wood

- Machinery

- Joins, preventive treatments and coatings

- Processed products: type of furniture and estimated production quantity

- Needs, support received and suggestions

- Promotion of the generation and sustainability of the timber resource and knowledge of the production license procedure. (Proposed by the ICF).

\section{Identification and choice of strategies}

After defining the SWOT matrix, we identified different strategic approaches, such as seeking to reduce the weaknesses (defensive strategy) or increase the strengths (reactive strategy), avoiding weaknesses that interfere with opportunities (adaptive strategy) or increasing strengths to improve our opportunities (offensive strategy) (Talancón 2007). We must find the most profitable strategy in each case. We therefore pose a series of questions in order to establish a decision-making process (Johnson and Scholes 1997):

- Opportunity of the strategy: which option plays to the organisation's strong points, overcomes its weaknesses and exploits opportunities, while minimising the risks in the environment?

- Feasibility of the strategy: how far can the strategic option be applied? Can the necessary funding be obtained? Can the necessary staff be recruited and trained in time? An acceptable selection 
criterion involves knowing what risks are acceptable.

Although the selection criteria are useful, there is unlikely to be a clear delimitation between a correct and an incorrect strategy, as any choice inevitably entails risks or drawbacks. The choice is therefore ultimately a matter of assessing the management.

\section{Strategic implementation}

This refers to the way the strategy is translated into action by designing and structuring the sector, planning the resources and managing the strategic change. The success of the strategy will depend on the degree to which these elements are effectively integrated to create competencies which all the other organisations have difficulty in imitating.

The following questions were also raised about the implementation of the strategy: who is responsible for implementing the strategy? What changes must be made in the design of the organisational structure? What tasks need to be done? What changes must be made in the resources?

\section{RESULTS AND DISCUSSION}

Honduras is the $129^{\text {th }}$ country in the Human Development Index (HDI) of the PNUD, with a value of 0,617 and has large sources of forest product. Forest Industry employed more than 150000 people, (Morales 2002) with an minimum wage of 10,45 (Fundación Wage Indicator 2015).

It is considered as an extreme violent country with more than 90 intentional homicides per 100000 people (Worldbank 2015).

Although there are many illegal forest operations, some negotiations with international stakeholders as the AVA (Acuerdo Voluntario de Asociación) between the UE and the Honduras Government that considered the principles from the FLEGT program of the UE (Forest Law Enforcement, Governance and Trade) are making progresses for the regulation of the forest industry (Wilberto 2015).

On internal analysis, we contacted a total of 60 carpentry or woodworking firms or small-scale industries in the five municipalities in the Yoro Model Forest, after obtaining the following information:

Company organisation: $82 \%$ of the companies have a nominal organisation, and log the entry of raw materials, costs, product orders, scheduling, yields, quality control and so on. They only record the invoices for timber purchases when required by the legislation. The company sets the price of the end product intuitively based on the expected costs of the raw materials and the estimated number of hours taken to produce the product. The production of the remaining $18 \%$ of the firms is sold outside Yoro, and they maintain -in a rudimentary way- a more extensive record of the entry of raw materials, costs, product orders, scheduling, yields, quality control and so on.

Most of the firms (85\%) have their facilities next to their homes, in barns (53\%), all of which have electrical power (usually two combined currents of 110 and 220 volts) and a telephone (except three firms); only one firm has a dryer, and two have an office.

The fixed machinery in all the firms consists of a circular table saw (except one firm), drill in the axis of the circular saw (except five firms) and planer (except seven firms). Only around $25 \%$ of the respondents have a mortising machine, moulder and thickness planer. Only two firms have a tenoning machine. Portable machinery commonly includes portable belt sanders, drills, routers, jigsaws and portable planers. For coating, 52\% have an airbrush gun, while the rest apply the finish with a brush, roller or cotton rag.

All the firms have two to four workers (the firm owner also works as a carpenter) and may occasionally have an apprentice or even -in the case of large orders- temporarily employ an assistant. The owners of these firms have very little education. Only 5\% have higher studies, $23 \%$ of the 
respondents have vocational training in carpentry, and the rest have primary $(33 \%)$ or secondary $(27 \%)$ education, or none at all. They are generally in early middle-age and only $5 \%$ are over 50 .

Timber consumption ranges between 0,7 and $3,5 \mathrm{~m}^{3} / \mathrm{month}$, normally in the form of block (with a width and thickness varying between 4, 6 and 8 inches and 7 or 8 feet long) supplied by "coyotes" or middlemen directly to their plants, without their knowing the source of the wood (normally illegal); although $38 \%$ of the respondents also admit they directly use the timber in the forest without the necessary authorisation. The most common species in order of use are: cedar (Cedrela odorata), Caribbean longleaf pitch pine (Pinus oocarpa.), Guatemalan rosewood (Dalbergia cubiquiltzensis), light American cordia (Cordia alliodora), cedar bitter (Cedrela fissilis.), aguacatillo (Ocotea irazuensis), cedrillo (Huertea cubensis), mahogany (Swietenia macrophylla, Species included in Appendix II of the Convention on International Trade in Endangered Species of Wild Fauna and Flora (CITES), tropical walnut (Juglans olanchana.), tamboril (Enterolobium cyclocarpum), white mahogany (Tabebuia donnell-smithii), and bully tree (Hyeronima alchorneoides). Fourteen more species were mentioned, although exceptionally, and always by fewer than half of the companies interviewed.

With regard to workshop techniques, it is worth noting that $92 \%$ of the respondents dry the timber vertically with occasional rotation (only $75 \%$ of the respondents) and for a period ranging between 10 and 40 days, with an average of 15 days for 1 inch thicknesses, and 30 days for 2 inch. Only 27\% admitted that the wood was not totally dry, which became clear in the application of the coating. None of the respondents acknowledged the problem of juvenile wood. The joinery used is $50 \%$ butt joints and $50 \%$ tongue and groove, always applying polyvinyl acetate glues. From most to least common, the joints are: tongue and groove reinforced with screws or nails, mortise and tenon, biscuit, dowel, and finally staples. In no case are dovetail joints used. The coating is usually based on applying sealers and subsequently a topcoat of shellac $(64 \%)$, polyurethane $(47 \%)$ or nitrocellulose $(20 \%)$. In the case of pine, the usual practice is to apply an anti-termite product (41\%) and then a dye prior to sealing $(100 \%)$. Finally, only $45 \%$ of the respondents were able to estimate the yield of the raw material, which was ventured at around $55-65 \%$.

Most firms work only with orders from private individuals in the community where they live or nearby; four produce stocks for companies outside the region, and another seven firms sell to intermediaries who market the furniture outside the region. All, or almost all of them manufacture the following products: doors with doorframes and subframes, rods, cupboards, kitchen cabinets, chests of drawers, tables and bookshelves, and to a lesser extent (by just over half the companies): cots, windows, chairs, coffins; while some entrepreneurs make carved handicrafts, blinds, chests of drawers, office furniture and so forth.

In the section on needs, support and suggestions, practically all the firms highlighted the need to tackle common problems in a cooperative way. $27 \%$ expressed an interest in improving the technology, another $27 \%$ in improving their technique, $22 \%$ in resolving their problems with coatings, $18 \%$ pointed out the need for support in finding markets and $8 \%$ in upgrading their facilities.

Finally, the questions on the generation and sustainability of the timber resource and knowledge of the procedures for production licenses revealed that most were aware of the existence of forestry plantations created in recent years in the model forest and in the surrounding area. They admit that most of the timber they process is illegal, although they do not relate this directly to deforestation -which tends to be more closely associated with extending the areas suitable for farming- but attribute it to the legal impediments for its use. Only $23 \%$ were acquainted with forestry certification but none of them acknowledged the need for it.

Regarding the Yoro Model Forest, it is remarkable that: it covers an area of 321219 ha, and includes five municipalities in the Yoro Department, namely Jacón, Yoro, Yorito, Sulaco and Victoria. The total number of inhabitants is 132,679; of whom $90 \%$ are of European descent and $10 \%$ are from other ethnic groups (Xicaque and Tolupanes). $56 \%$ of the population is rural, $68 \%$ lives in poverty and $17 \%$ in extreme poverty. The average monthly income is US $\$ 80$ per capita, and there is a $32 \%$ recorded rate of illiteracy and a 34\% rate of infant malnutrition (RIABM, 2015).

130210 ha of the area is state-owned and 191009 ha privately owned; $60 \%$ of its area is forested (36\% coniferous species, $15 \%$ broadleaved species, $7 \%$ mixed and $2 \%$ other), and the rest is used for 
farming and livestock (40\%). The landscape contains a vast wealth of ecosystems and flora and fauna which has led to the declaration of 22887 ha as protected areas.

The local stakeholders on the management committee of the Yoro Model Forest comprise: Xicaque tribes and the federation of Xicaque tribes, forestry groups and forestry industry associations, institutions of the State of Honduras, municipal authorities and the leaders of municipal associations, NGOs, PDOs (private development organisations), forestry firms, private banks, the Chamber of Commerce, primary, secondary and higher education institutions, (U-ESNACIFOR), community organisations, agricultural and livestock farming associations, private forest owners' associations, and representatives of national (such as PBPR) and international aid agencies such as the Agricultural Development Project, Ayuda en Acción, Movimiento por la Paz, and Visión Mundial.

Yoro is the site of two important sawmills (Yodeco de Honduras which produces $40000 \mathrm{~m}^{3}$ and Foresta Beta which produces $16000 \mathrm{~m}^{3}$ ), in addition to forestry cooperatives and groups integrating 1725 members, primarily engaged in forestry production, although some work in resin production and forestry protection (Morales et al. 2002).

With the help of the ICF, 18 forestry plantations were located in the Yoro Model Forest, with areas of between 1,4 and 108 ha and created between 2005 and 2013. The species they contain include mahogany, cedar, laurel, African mahogany and khaya (Khaya senegalensis A. Juss.) and teak (Tectona grandis L. f.), and they are located near the main road where a significant supply of wood could be generated from both thinning and final cutting, with a number of possibilities for forest management and chain of custody certification.

\section{SWOT analysis}

The summary of the SWOT matrix is as follows:

\begin{tabular}{|c|c|}
\hline Strengths & Weaknesses \\
\hline $\begin{array}{l}\text { Entrepreneurial spirit } \\
\text { - Availability and variety of raw material at } \\
\text { very economical prices } \\
\text { - Ability to be flexible in the manufacture } \\
\text { of products }\end{array}$ & $\begin{array}{l}\text { - Consumption of illegal timber } \\
\text { Ignorance of business techniques, } \\
\text { particularly financial and marketing skills } \\
\text { Quality problems of due to lack of drying } \\
\text { Minimal local demand }\end{array}$ \\
\hline Opportunities & Threats \\
\hline $\begin{array}{l}\text { - Increase in the value of the end products } \\
\text { by improving yields and product quality. } \\
\text { Possibility of exploiting woods from } \\
\text { timber plantations with forestry } \\
\text { certification. } \\
\text { Possibility of association and strategic } \\
\text { alliances. }\end{array}$ & $\begin{array}{l}\text { - Political instability and lack of security. } \\
\text { - Risk of closure of the firm due to the use of } \\
\text { illegal raw material. }\end{array}$ \\
\hline
\end{tabular}

This matrix coincides fairly closely with the results of the study by Mejía et al. (1996), although it is worth noting the following discrepancies:

- The international recognition of the quality of the products is not highlighted as a strength but rather as a weakness.

- The opportunity of using the thinnings is seen as real, but is not considered sufficiently important. However the improvement in the product yields is viewed as relevant.

- The increase in aggregate value due to improved coatings is seen as a minor opportunity, unless the issue of incorrect drying is first resolved.

- The situation of political and social insecurity is seen as a threat to the real possibilities of development, as is the possible closure of workshops using illegal timber as a result of the Voluntary Partnership Agreement (VPA) currently in place between Honduras and the European Union, as indicated earlier. 


\section{Strategic choice}

The following strategies can be derived from the SWOT matrix: techniques.

- Defensive strategies: purchase of legal wood; training in business techniques and drying

- $\quad$ Reactive strategies: marketing the products outside the Department of Yoro.

- Adaptive strategies: promoting the purchase of legal wood and the joint installation of a dryer through a business association in the form of a cooperative.

- Offensive strategy: seeking out strategic alliances in foreign markets to allow companies to supply duly acquired, dried and mechanised furniture parts.

With regard to the "opportunity of the strategy", the option that plays to the strong points, overcomes weaknesses and exploits the opportunities while minimising the risks of the environment is the offensive strategy.

The issue of the "feasibility of the offensive strategy" can be met by taking into account that trends in furniture design (Daniel 2014, Lecuona 2012) are becoming increasingly oriented towards the intangible values of products that evoke distant countries (glamour), mystery and exoticism, with a clear aspiration to appear distinctive, and -of course- the allure of environmentally friendly furniture. However, it is first necessary to improve the organisation of the craftsmen in order to boost their production capacity, increase their yield and quality, and obtain products with a certificate of sustainability.

The following changes are required in order for the strategy of an alliance with an international company for the supply of furniture parts to be feasible (in order of importance):

- $\quad$ They must only acquire legal wood with forestry certification.

- They must associate in a cooperative that enables them to organise as a business and increase their production capacity.

- They must dry the wood adequately.

- $\quad$ They must acquire knowledge and skills in quality management.

\section{Strategic implementation}

The steps required to meet these objectives can be achieved through the following actions and in the following sequence: 
- Development of technical skills. This was established as the first action, both to enable the workers to improve the woodworking knowledge and techniques, and for them to perceive the need to organise themselves as a group and understand the strategic objectives. (This action was implemented through the project UPM/ESNACIFOR Support for the development of timber micro-industries in Yoro (WOODWORKERS), with the collaboration of the Yoro Model Forest, endowed with $€ 35,380$.)

- Formation of a cooperative, Ebanistas Yoreños LTDA. (COOPIEYOL), initially comprising 35 members with statutes that are open to any workshop and with an established organisational model headed by a chairman who manages the administrative, financial and economic affairs of the cooperative with the support of a professional manager, and elements to control the cooperative.

- $\quad$ Plan for purchasing timber from plantations near the city of Yoro. (Created by the engineer Manuel Donadi, (UPM) and supported by ESNACIFOR with an endowment of $€ 2,300$.)

- Installation of a purchasing and wood-processing centre, equipped with a horizontal mill saw, a solar dryer (actually three units), a planer and a thickness planer. (This action was possible thanks to the project UPM/ESNACIFOR Support for the development of timber micro-industries in Yoro: Provision of a Purchasing Centre, with the collaboration of the Yoro Model Forest Association and the Municipality of Yoro, and endowed with a budget of $€ 34.507$.

- Developing the genuine common activity of the cooperative through the purchasing centre, adjusting the prices of the timber to each of the cooperative members, and sharing the problems of timber quality, service quality, cost study, and so on. For the time being the activity has only just begun, and a period of induction is necessary. The cooperative members are undergoing the typical teething troubles of all business organisations.

- $\quad$ Business training to solve the problems of managing the cooperative and to serve as the basis to be able to tender as a provider of furniture parts on the international market.

- Strategic alliance with an international furniture manufacturing company that shares the ideas of natural, certified, environmentally-friendly products, and which follows a policy of social engagement through cooperation with companies in developing countries.

The installation of the purchasing centre is pending the arrival of electricity and the completion of the construction of the driers. Furthermore, of the 35 initial members there are now only 16 remaining from 11 companies, but all clearly committed to going forward. They purchase the timber legally normally from plantations-, and cut, process, transport and prepare it themselves at a very competitive prices compared to illegal timber. They have signed a commitment with the ICF to comply with the Voluntary Partnership Agreement (VPA). 


\section{CONCLUSIONS}

The main goal of this study was to generate a strategic model that could improve the wellbeing of our communities and provide a sustainable business model for the local forest industries in the Yoro Model Forest. We firmly believe that the strategic model proposed could provide the foundations for the sustainable development of local forest industries, while maintaining a balance with the stakeholders' interests and the environment.

We then studied its applicability to other Model Forests. Each one is unique, but they all share a set of common factors such as ready availability of local raw materials, low labour costs and a large number of micro-industries managed by craftsmen and entrepreneurs. An analysis of the social and economic conditions in some of the Latin American Model Forests in the RIABM (International Model Forest Network Association) established that the model proposed in this study could have direct applicability for Model Forests such as La Atlántida and Noreste de Olancho in Honduras; the Chuiquitano in Bolivia, Choroteca in Costa Rica and Quezaltenango in Guatemala, all of which have similar conditions to the Yoro Model Forest in Honduras.

Further studies are needed in order to apply this strategic model to different candidates outside this geographic area or with different conditions. However it would appear that forests that share these same three key factors could be potential candidates for the positive deployment of this strategic model.

\section{REFERENCES}

Daniel, D. 2014. Fresh furniture trends to watch for in 2014 Freshhome. Interior, Design \& Architecture. [on line]<http://freshome.com/2014/04/02/15-fresh-furniture-trends-watch2014/>[Accesed 10/04/2015]

Fundación WageIndicator, 2015. [on line]<http://www.tusalario.org/honduras/portada/salario/ salario-minimo $>$ [Accesed 10/04/2015]

García-Jiménez, A.F.; Vásquez-Leyva, O; Aguilar-Lazo, Z.M. 2013. Plan estratégico para la industria de muebles en Lambayeque.

Gil-Zafra, M.A. 2001. Planificación estratégica "método DAFO" en prácticas locales de creatividad social, in: El Viejo Topo (Ed.), Prácticas Locales De Creatividad Social. El Viejo Topo, España, pp. 123-14.

Hill, C.W. 2007. Negocios internacionales. $1^{\circ}$ ed. Mc Graw Hill, México.

IUDPS. 2013. Boletin No32 Observatorio de la violencia. [on line] <http://www.iudpas.org/pdf/ Boletines/Nacional/NEd32EneDic2013.pdf $>$ [Accesed 10/04/2015]

IMFN. 2011. La red internacional de bosques modelo: Un enfoque global para la sostenibilidad de los ecosistemas. 60p. ISBN: 978-0-662-03479-7 
Johnson, G.; Scholes, H. 1997. Dirección estratégica: análisis de la estrategia de las organizaciones. $3^{\mathrm{a}}$ ed. Prentice Hall, México.

Jum, C.; Nguiebori, J.; Zoa-Mireille, Z.; Diaw, C. 2007. The model forest experience in Cameroon. ITTO Tropical Forest Update 17(2): 11-17.

Lecuona, M. 2012. El mercado y el consumo de los 90 y primeros años del siglo XXI. AIDIMA. [on line]<http://www.clustermadeira.com/pdf/Dise\%C3\%B1o_01.pdf > [Accesed 05/04/2015].

Malik, K. 2014. Human Development Report 2014: Sustaining Human Progress: Reducing Vulnerabilities and Building Resilience. New York: United Nations Development Programme.[on line]<http://hdr.undp.org/sites/default/files/hdr14-report-en-1.pdf> .

Mejía, M. A.; Vlosky, R. P.; Shupe, T.; Aguilar, F. X. 1996. Participatory analysis of the strengths, weaknesses, opportunities and threats to small and medium wood product enterprises in Siguatepeque and San Pedro Sula, Honduras. Recursos Naturales y Ambiente (CATIE). [on line]<http://www.sidalc. net/repdoc/A3296e/A3296e.pdf> [Accesed 05/04/2015].

Morales, J.; Marx, C.; Serrano, O. 2002. Estado de la información forestal en Honduras. Monografías de Países 10 FAO, 131.

Palacios, R.; Vaides, R. 2011. Sistematización de la Estrategia Forestal de la Ecorregión Lachuá, Cobán, in: Anonymous Proyecto Kedlap: Investigaciones Y Sistematizaciones De Los Bosques Modelo. CUSO-VSO, RIAB,CEBEM, .

Rauch, P. 2007. SWOT analyses and SWOT strategy formulation for forest owner cooperations in Austria. European Journal of Forest Research 126: 413-420.

RIABM. 2015. Bosques modelo: Territorios de desarrollo sostenible: YORO. [on line] $<\mathrm{http}: / /$ www.bosquesmodelo.net/yoro/> [Accesed 14/04/2015].

Richards, M.; Wells, A.; del Gatto, F.; Contreras-Hermosilla, A.; Pommier, D. 2003. Impacts of illegality and barriers to legality: a diagnostic analysis of illegal logging in Honduras and Nicaragua. International Forestry Review 5: 282-292.

Serna-Gómez, H. 1994. Planeación y gestión estratégica. Legis Editores.

Talancón, H.P. 2007. La matriz FODA: alternativa de diagnóstico y determinación de estrategias de intervención en diversas organizaciones. Enseñanza e Investigación en Psicología 12: 113-130.

Vallejo, P.M. 2011. Guía para construir cuestionarios y escalas de actitudes. Universidad Pontificia de Comillas, España.

Wilberto, R. 2015. La Unión Europea y Honduras avanzan en acuerdo para asegurar la legalidad de la madera. La Tribuna. [on line]<http://www.latribuna.hn/2015/02/01/la-union-europea-y-hondurasavanzan-en-acuerdo-para-asegurar-la-legalidad-de-la-madera $>$ [Accesed 2015/02/01] 
Worldbank. 2015. Intentional homicides. [on line]<http://data.worldbank.org/indicator/VC.IHR. PSRC.P5?order=wbapi_data_value_2012+wbapi_data_value+wbapi_data_value-last\&sort=desc $>$. [Accesed 2015/02/01]. 